\title{
Houttuynia cordata Thunberg exhibits anti-tumorigenic activity in human gastric cancer cells
}

\author{
Se Chul Hong ${ }^{1 \#}$, Hyun-JiEo ${ }^{2}$, Hoon-MinSong ${ }^{2}$, So-HeeWoo ${ }^{2}$, Mi-KyeongKim ${ }^{2}$, \\ Jin-WookLee ${ }^{2}$, Jeong-MinSeo ${ }^{2}$, Su-BinPark ${ }^{2}$, Jung-HyeEom ${ }^{2}$, JinSukKoo ${ }^{2}$, \\ JinBooJeong ${ }^{2 *}$ \\ 1 : International Ginseng \& Herb Research Institute, Geumsan, 312804, Korea \\ 2 : Department of Medicinal Plant Resources, Andong National University, Andong, 760749, Korea
}

\begin{abstract}
Objectives : Gastric cancer is a leading cause of cancer-related deaths, worldwide. Houttuynia cordata Thunberg ( $H$. cordata) has been used as a medicinal plants and it has an anti-cancer activity in human colorectal cancer and leukemic cancer. However, the potential anti-cancer activity and mechanisms of $H$. cordata for human gastric cancer cells have not been tested so far. Thus, this study examined the biological effects of $H$. cordata on the human gastric cancer cell line SNU-1 and AGS.

Methods : Inhibition of cell proliferation and cell cycle by $H$. cordata was carried out by MTT assay and Muse cell cycle analysis and the expressions of protein associated with apoptosis and cell cycle regulation were investigated with Western blot analysis.

Results : In MTT assay, the proliferation of SNU-1 and AGS cells was significantly inhibited by $H$. cordata in a time and dose dependent manner, Inhibition of cell proliferation by $H$. cordata was in part associated with apoptotic cell death, as shown by changes in the expression ratio of Bax to Bcl-2 by $H$. cordata. Also, H. cordata regulated the expression of cell cycle regulatory proteins such as pRb, cyclin D1, cyclin E, CDK4, CDK2, p21 and p15.

Conclusion : The antiproliferative effect of $H$. cordata on SNU-1 and AGS gastric cancer cells revealed in this study suggests that $H$. cordata has intriguing potential as a chemopreventive or chemotherapeutic agent.
\end{abstract}

Key words : Anti-cancer activity; Apoptosis; Human gastric cancer; Houttuynia cordata Thunberg

\section{Introduction}

Gastric cancer is one of the leading causes of cancer incidence and mortality around the world ${ }^{1)}$. Although surgeryis the most effective therapy for gastric cancer, chemoprevention has been regarded as a promising strategy to reduce the incidence of gastric cancer. Thus, nowadays, many researchers have investigated the promising anti-cancer agents and found that natural compounds are important sources for cancer chemopreventive and chemotherapeutic agents.

Houttuynia cordata Thunberg ( $H$. cordata) has been used as a vegetable and herbal plant and it is estimated that $H$. cordata has anti-inflammatory ${ }^{2}$, anti-cestodal $^{3)}$, anti-viral ${ }^{4)}$ and anti-obesity effects ${ }^{5)}$. and induces apoptosis in human colorectal cancer cells $^{6,7)}$ and leukemic cancer cells ${ }^{8)}$. However, the potential anti-cancer activity and mechanisms of $H$. cordata for human gastric cancer cells have not been tested so far. Thus, in light of the therapeutic potential of $H$. cordata in human gastric cancer, this study was performed to elucidate the potential mechanism by which $H$. cordata induces the cell growth arrest and apoptosis in human gastric cancer cells. Here, for the first time, we report that $H$. cordata leads to cell growth arrest and apoptosis

\footnotetext{
*Corresponding author : Jin Boo Jeong. Department of Medicinal Plant Resources, Andong National University, Andong, Korea, 760749. - Tel : +82548207757 · Fax : +82 8206252 ·E-mail : jjb0403@anu.ac.kr

\#First author : Se Chul Hong. International Ginseng \& Herb Research Institute, Geumsan, Korea, 312804

· Tel : +82417501643 ·E-mail : hsc0684@gmail.com

· 접수 : 2013년 10월 23일 · 수정 : 2013년 11월 09일 ·채택 : 2013년 11월 12일
} 
which may be associated with the regulating cell cycle-regulatory proteins and $\mathrm{Bax} / \mathrm{Bcl}-2$ ratio in human gastric cancer cells.

\section{Materials and Methods}

\section{Chemicals}

Cell culture media, RPMI 1640 was purchased from Life Technologies (Grand Island, NY, USA). Antibodies against Bax, Bcl-2 and p21 were purchased from Santa Curz Inc. (Santa Cruz, CA, USA) and other antibodies against cyclin D1, cyclin E, CDK2, CDK4, $\mathrm{p} 15$, phospho-Rb (ser780) and $\beta$-actin were purchased from Cell Signaling (Danvers, MA, USA). All chemicals were purchased from Fisher Scientific, unless otherwise specified.

\section{Sample preparation}

H. cordata was kindly provided by Bonghwa Alpine Medicinal Plant Experiment Station, Korea. One kilogram of $H$. cordata was extracted with 2L of $80 \%$ methanol with shaking for 24 hours. After 24 hours, the extract with $80 \%$ methanol was filtered, concentrated to approximately $400 \mathrm{ml}$ volume using by a vacuum evaporator, and subsequently fractioned with ethyl acetate in a separating funnel. The ethyl acetate fraction (42 g, yield rate: $4.2 \%$ ) was separated from the mixture and evaporated by a vacuum evaporator. Ethyl acetate fraction was kept at $-80{ }^{\circ} \mathrm{C}$.

\section{Cull culture and treatment}

Human gastric cancer cell lines (SUN-1 and AGS) and human normal gastric epithelial cells were purchased from American Type Culture Collection (Manassas, VA, USA) and grown in RPMI 1640 supplemented with $10 \%$ fetal bovine serum (FBS), 100 $\mathrm{U} / \mathrm{ml}$ penicillin, and $100 \mu \mathrm{g} / \mathrm{ml}$ streptomycin. The cells were maintained at $37{ }^{\circ} \mathrm{C}$ under a humidified atmosphere of $5 \% \mathrm{CO}_{2}$. Ethyl acetate fraction from $H$. cordata was dissolved in dimethyl sulfoxide (DMSO) and treated to cells. DMSO was used as a vehicle and the final DMSO concentration was not exceeded $0.1 \%$ $(\mathrm{v} / \mathrm{v})$.

\section{MTT assay}

SNU-1, AGS and human normal gastric epithelial cells $\left(1 \times 10^{5}\right.$ cells) were plated onto 96-well plate and grown overnight. The cells were treated with $0,5,2550$ $\mu \mathrm{g} / \mathrm{ml}$ of extracts in media for 24 and 48 hours at $37{ }^{\circ} \mathrm{C}$ under $5 \% \mathrm{CO}_{2}$. Then, the cells were incubated with $50 \mu \mathrm{l}$ of 3-(4,5-dimethylthiazol-2-yl)-2,5-diphenyltetrazolium bromide (MTT) solution ( $1 \mathrm{mg} / \mathrm{ml}$ ) for an additional 4 hours and then the formazan crystal produced was measured by an enzyme-linked immunosorbent assay reader at $570 \mathrm{~nm}$. Cell growth inhibition was estimated as the reduction in values from a vehicle.

\section{Cell cycle analysis}

Cell cycle analysis was carried out using Muse $\mathrm{MM}^{\mathrm{TM}}$ Cell Cycle Kit (Millipore, Billerica, MA, USA) according to the manufacturer protocol. Briefly, the cells treated with ethyl acetate fraction from $H$. cordata were harvested, centrifuged at $300 \mathrm{x} \mathrm{g}$ for $5 \mathrm{~min}$, and then washed once with 1 x PBS. One milliliter of ice cold $70 \%$ ethanol was added to cells and then cells were incubated for 3 hours at $-20{ }^{\circ} \mathrm{C}$. After 3 hours, $200 \mu \mathrm{l}$ of fixed cells were transferred into new tubes, centrifuged at $300 \mathrm{x} \mathrm{g}$ for $5 \mathrm{~min}$, and then washed once with 1 x PBS. After washing, cells were stained with $200 \mu \mathrm{l}$ of Muse $^{\mathrm{TM}}$ Cell Cycle reagent at the room temperature in the dark for $30 \mathrm{~min}$, and subsequently cell cycle was analyzed using Muse ${ }^{\mathrm{TM}}$ Cell Analyzer.

\section{SDS-PAGE and Western blot}

The cells were washed with $1 \mathrm{x}$ phosphated-buffered saline (PBS), and lysed in NP-40 lysis buffer supplemented with protease and phosphatase inhibitor cocktail (Sigma Aldrich, St.Louis, MO, USA), and centrifuged at $15,000 \mathrm{x} \mathrm{g}$ at $4{ }^{\circ} \mathrm{C}$ for $20 \mathrm{~min}$. After protein concentration was determined by Bradford protein assay. Equal amounts of proteins were subjected to SDS-PAGE and then transferred onto PVDF membrane. The membranes were blocked for non-specific binding with 5\% non-fat dry milk in tris-buffered saline containing $0.05 \%$ Tween 20 (TBS-T) for 1 hour at room temperature and then probed with the primary antibodies overnight at $4{ }^{\circ} \mathrm{C}$, followed by incubation with horse radish peroxidase (HRP)-conjugated immunoglobulin G (IgG) for 1 hour at room temperature. Chemiluminescence was detected with ECL Western blotting substrate (GE Healthcare, Pittsburgh, PA, USA) and visualized in polaroid film.

\section{Statistical analysis}

Statistical analysis was performed with the Students unpaired t-test, with statistical significance set at *, $P<0.05$ 


\section{Results}

\section{Effect of the extracts from $H$. cordataon} cell proliferation and cell cycle progression in human gastric cancer cells and normal gastric epithelial cells

We investigated whether the extracts from $H$. cordata affects the proliferation of human gastric cancer cells. SNU-1 and AGS cells were treated with 0, 5, 25, 50 $\mu \mathrm{g} / \mathrm{ml}$ of the extracts for 24 and 48 hours. As shown in Fig. 1A, the extracts resulted in a significant reduction of cell growth by 53\% and $71 \%$ at 25 and $50 \mathrm{\mu g} / \mathrm{ml}$ of the extracts at 24 hours, and $12 \%, 80 \%$ and $82 \%$ at 5,25 and $50 \mu \mathrm{g} / \mathrm{ml}$ of the extracts at 48 hours in AGS cells, respectively. We also observed that the extracts reduced the cell growth of SNU-1 by $13 \%$ and $31 \%$ at 25 and $50 \mu \mathrm{g} / \mathrm{ml}$ of the extracts at 24 hours, and $15 \%, 52 \%$ and $70 \%$ at 5, 25 and 50 $\mathrm{\mu g} / \mathrm{ml}$ at 48 hours, respectively (Fig.1B). However, the extracts induced the minimal cell growth arrest in normal gastric epithelial cells (Fig. 1C). In addition, we analyzed the effect of the extracts from $H$. cordata on cell cycle progression to determine if inhibition of cell proliferation by the extracts from $H$. cordata was resulted from cell cycle arrest. As shown in Fig. $2 \mathrm{~A}$ and $2 \mathrm{~B}$, the extracts from $H$. cordata significantly inhibited G1/S transition in SNU-1 and AGS cells. These data indicate that $H$. cordata may have an anti-cancer activity in human gastric cancer cells and this activity may be cancer-specific.

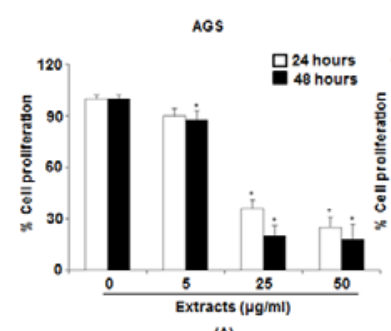

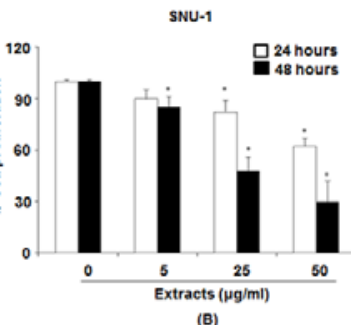

(B)

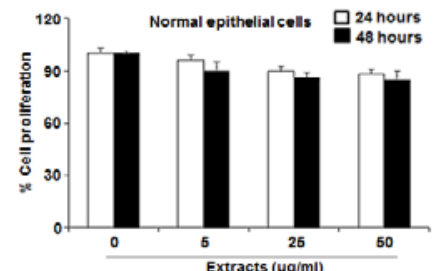

(c)

Fig. 1. Effect of $H$. cordata on cell proliferation in human gastric cancer cells, AGS and SNU-1. The effects of $H$. cordata on cell proliferation were measured by MTT assay. The values of absorbance were calculated as \% cell proliferation. The cells without $H$. cordata were treated with DMSO. Statistical analysis was performed with the Student' $s$ unpaired t-test, with statistical significance set at ${ }^{*}, P<0.05$.

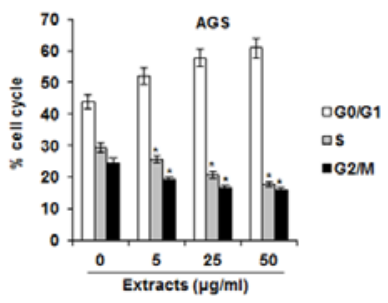

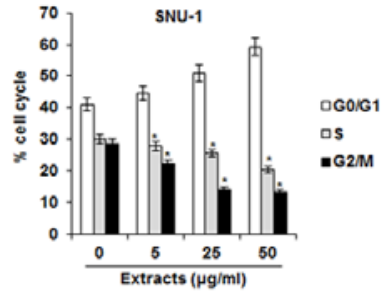

Fig. 2. Effect of $H$. cordata on cell cycle progression in human gastric cancer cells, AGS (A) and SNU-1 (B). Cell cycle progression was measured by Muse cell cycle analysis. The values of absorbance were calculated as \% cell cycle. The cells without $H$. cordata were treated with DMSO. Statistical analysis was performed with the Student' $s$ unpaired t-test, with statistical significance set at ${ }^{*}, \mathrm{P}<0.05$.

\section{Effects of the extracts from $H_{\text {. cordata }}$}

\section{on the expression of Bax and Bcl-2}

To determine whether the extracts from $H$. cordata induce apoptosis in SNU-1 and AGS cells, the expression levels of Bax and Bcl-2 were evaluated by Western blot. Overexpression of Bcl-2, one of the anti-apoptotic proteins and down-regulation of Bax, one of the pro-apoptotic proteins mediates resistance to apoptosis in cancer cells ${ }^{9)}$. As shown in Fig. $3 \mathrm{~A}$ and $3 \mathrm{~B}$, the extracts from $H$. cordata induced overexpression of Bax in both SNU-1 and AGS cells, while it did not affect the expression levels of Bcl-2.

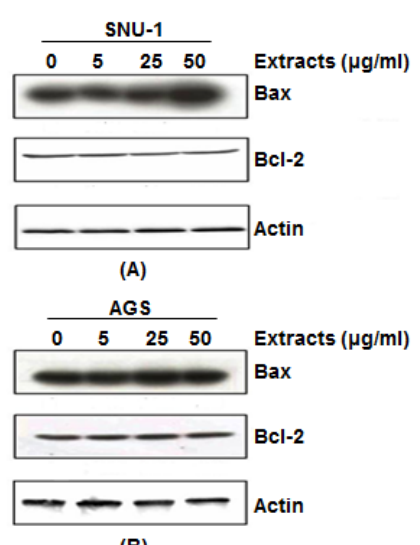

Fig. 3. Effect of $H$. cordata on the expression of $\mathrm{Bcl}-2$ and Bax. SNU-1 (A) and AGS (B) cells were cultured in 6-well plate in presence of $H$. cordata for $48 \mathrm{~h}$ and equal amount of protein (40 $\mu \mathrm{g})$ from cell lysates was subjected to SDS-PAGE as described in Materials and methods. Relative ratio was calculated using the software Un-SCAN-IT gel Version 5.1 (Silk Scientific, Inc.). The cells without $H$. cordata were treated with DMSO.

\section{Inhibitory effect of the extracts from $H$.} cordata on the expression of cell cycle-regulatory proteins

One of the major cell cycle regulators is retinoblastoma protein $(\mathrm{pRb})$ which is considered to be a potent 
tumor suppressor. It inhibits the E2F family transcription factors for transition to $\mathrm{S}$ phase, resulting in control of the cell cycle at the $\mathrm{G}_{1}-\mathrm{to}_{\mathrm{-}}$-Sphasecheckpoint ${ }^{10,11)}$.

Hypophosphorylated pRb inhibits cell cycle progression by associating with E2F, while sequential $\mathrm{pRb}$ phosphorylation results in G1/S transition ${ }^{12-14)}$. Based on this literature, we tested the regulation of $\mathrm{pRb}$ phosphorylation by $H$. cordata to determine whether the cell growth inhibition by $H$. cordata is mediated from cell cycle arrest. As shown in Fig. 3A and 3B, H. cordata down-regulated pRb phosphorylation at Ser780 in both SNU-1 and AGS cells. There are growing evidence that pRB phosphorylation is induced by the complex between cyclin $\mathrm{D}$ and cyclin dependent kinase (CDK) 4/6, and cyclin E and CDK2 ${ }^{12-14)}$. Thus we also investigated the expression levels of cyclin D1, cyclin E, CDK4 and CDK2 by Western blot. As results, expressions of cyclin D1, cyclin E, CDK4 and CDK2 were suppressed by the treatment of $H$. cordata at the dose-dependent manner in SNU-1 and AGS cells (Fig. 4A and 4B). Tumor suppressor proteins, p21 and p15 regulate cell cycle progression by inhibiting the activity of cyclin E/CDK2 and cyclin D1/CDK4 complex $^{15,16)}$. As shown in Fig. $4 \mathrm{~A}$ and 4B, p21 and p15 were down-regulated in SNU-1 and AGS cells without $H$. cordata, but $H$. cordata dose-dependently up-regulated the expression of p21 and p15 in AGS and SNU-1 cells.
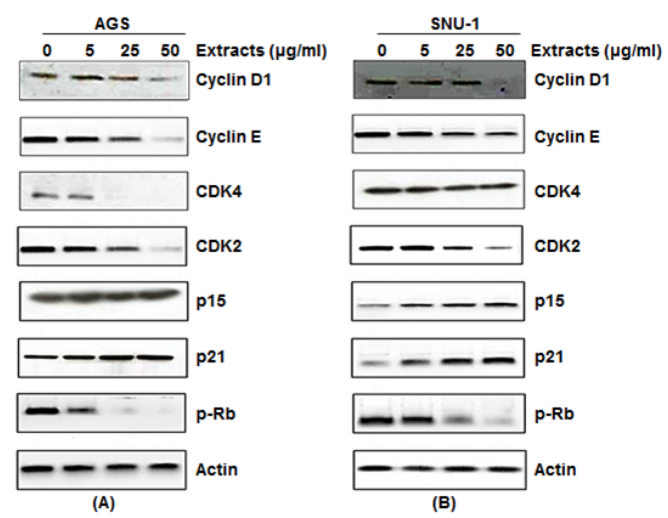

Fig. 4. Effect of $H$. cordata on the expression of cell cycle regulatory proteins. AGS (A) and $S N U-1$ (B) were treated with $H$. cordata for $48 \mathrm{~h}$ and equal amount of protein $(40 \mathrm{\mu g})$ from cell lysates was subjected to SDS-PAGE as described in Materials and methods. The cells without $H$. cordata were treated with DMSO. Relative ratio was calculated using the software Un-SCAN-IT gel Version 5.1 (Silk Scientific, Inc.).

\section{Discussion}

Among cancers, gastric cancer is a leading cause of cancer-related deaths worldwide ${ }^{17)}$. Recently, chemoprevention has received a great attention, and herbal medicinal plants have been recognized as an effective anti-cancer agent ${ }^{18)}$. There are some reports that $H$. cordata inhibits cell growth and induces apoptosis in human colorectal cancer cells ${ }^{6,7)}$ and leukemic cancer cells ${ }^{8)}$. However, the potential anti-cancer activity and mechanisms of $H$. cordata for human gastric cancer cells have not been studied. Thus, this study was performed to elucidate the potential mechanism by which $H$. cordata induces the cell growth arrest and apoptosis in human gastric cancer cells.

Although apoptosis is a process that removes damaged cells, resulting in the maintenance of cell numbers, cancer cells avoid apoptosis in response to various physiologic stimuli ${ }^{19)}$. Therefore, the induction of apoptosis has been regarded as a major target for cancer chemoprevention. There is a growing advance that the process of apoptosis is associated with increase of Bax expression, a proapoptotic protein and degrease of Bcl-2 expression, anti-apoptotic protein ${ }^{20)}$. Thus, the ratio of $\mathrm{Bax}$ to $\mathrm{Bcl}-2$ is important in determining susceptibility to apoptosis ${ }^{21)}$. Although $H$. cordata did not affect Bcl-2 expression, it up-regulated Bax expression. Taken together, H. cordata induced the increase of the ratio of Bax to Bcl-2. Therefore, apoptosis was induced in $H$. cordata -treated SNU-1 and AGS.

More and more investigations indicated that cell cycle arrest and apoptosis are closely associated with cell proliferation ${ }^{22)}$. Also, the sensitivity to apoptosis often depends on the cell cycle ${ }^{23)}$. Many studies have shown that inhibition of the cell cycle has been considered as a target for cancer chemoprevention ${ }^{24)}$. Retinoblastoma protein (pRb) controls G1/S phase transition and is a major target of the cyclin-CDK complexes. The pathway controlled by pRb may be aberrant in most human cancers ${ }^{25)}$. In normal cells, $\mathrm{Rb}$ is functionally inactivated by multiple phosphorylations mediated sequentially by a series of cyclin-CDK complexes ${ }^{25)}$. Phosphorylation of Rb disrupts complexes with E2Fs, allowing for cell cycle progression into $\mathrm{S}$ phase $^{25)}$. G1-phase progression is mediated by the combined activity of the cyclinD1/Cdk4 and cyclin E/Cdk2 complexes ${ }^{23)}$. CyclinD1-associated kinase activity increases in mid-G1, while cyclin E/Cdk2 activity increases in late G1 and peaks in early $\mathrm{S}$ phase ${ }^{23)}$. We examined the effects of $H$. cordata on the expression of cell cycle-regulatory proteins in the G1 phase of the cell cycle. $H$. cordata suppressed the expression of cyclin D1, cyclin E, CDK4 and CDK2. In addition, $H$. cordata increased the expression of tumor suppressor proteins, $\mathrm{p} 15$ and $\mathrm{p} 21$. It has been reported that $\mathrm{p} 15$ inhibits CDK4 activity and p21 acts as broad specific inhibitors of cyclin $\mathrm{D}$ and $\mathrm{E}^{26)}$. These findings indicate that the inhibition of SNU-1 and AGS proliferation by 
H. cordata may be mediated from the cell cycle distribution,

\section{Conclusion}

In summary, the results of the present investigation indicate the below.

1. H. cordata inhibited cell proliferation in human gastric cancer cells, AGS and SNU-1.

2. H. cordata induced increase in Bax protein, while it did not affect Bcl-2 expression in AGS and SNU-1 cells

3. $H$. cordata down-regulated cell cycle regulatory proteins such as cyclin D1, CDK4, cyclin E and CDK2, while it activated the expression levels of tumor suppressor proteins, p21 and p15, which resulted in inhibition of $\mathrm{pRb}$ hyper-phosphorylation

In conclusion, this study demonstrates that human gastric cancer cells can be killed by $\mathrm{H}$. cordata and these antiproliferative and apoptotic effects of $\mathrm{H}$. cordata may account for some chemopreventive or chemotherapeutic effects on gastric cancer cells.

\section{Acknowledgement}

This work was supported by Basic Science Research Program through the National Research Foundation of Korea (NRF) funded by the Ministry of Education, Science and Technology (2011-0013786).

\section{References}

1. Jemal A, Bray F, Center MM, Ferlay J, Ward E, Forman D. Global cancer statistics. CA Cancer J Clin. $2011 ； 61 ： 69-90$.

2. Lee HJ, Seo HS, Kim GJ, Jeon CY, Park JH, Jang BH, Park SJ, Shin YC, Ko SG. Houttuynia cordata Thunb inhibits the production of pro-inflammatory cytokines through inhibition of the $\mathrm{NF}-\kappa \mathrm{B}$ signaling pathway in HMC-1 human mast cells. Mol Med Rep. 2013 ; 8 : 731-6.

3. Yadav AK, Temjenmongla. Anticestodal activity of Houttuynia cordata leaf extract against Hymenolepis diminuta in experimentally infected rats. J Parasit Dis. 2011 ; 35 : 190-4.

4. Chen X, Wang Z, Yang Z, Wang J, Xu Y, Tan RX,
Li E. Houttuynia cordata blocks HSV infection through inhibition of $\mathrm{NF}-\kappa \mathrm{B}$ activation. Antiviral Res. $2011 ; 92: 341-5$.

5. Miyata M, Koyama T, Yazawa K. Water extract of Houttuynia cordata Thunb. leaves exerts anti-obesity effects by inhibiting fatty acid and glycerol absorption. J Nutr Sci Vitaminol (Tokyo). 2010 ; $56: 150-6$.

6. Lai KC, Chiu YJ, Tang YJ, Lin KL, Chiang JH, Jiang YL, Jen HF, Kuo YH, Agamaya S, Chung JG, Yang JS. Houttuynia cordata Thunb extract inhibits cell growth and induces apoptosis in human primary colorectal cancer cells. Anticancer Res. $2010 ; 30$ : 3549-56

7. Tang YJ, Yang JS, Lin CF, Shyu WC, Tsuzuki M, Lu CC, Chen YF, Lai KC. Houttuynia cordata Thunb extract induces apoptosis through mitochondrial-dependent pathway in HT-29 human colon adenocarcinoma cells. Oncol Rep. 2009 ; 22 : 1051-6.

8. Banjerdpongchai R, Kongtawelert P. Ethanolic extract of fermented Thunb induces human leukemic HL-60 and Molt-4 cell apoptosis via oxidative stress and a mitochondrial pathway. Asian Pac J Cancer Prev. $2011 ; 12$ : 2871-4.

9. Miyashita T, Krajewski S, Krajewska M, Wang HG, Lin HK, Liebermann DA, Hoffman B, Reed JC. Tumor suppressor p53 is a regulator of bcl-2 and bax gene expression in vitro and in vivo. Oncogene. $1994 ; 9$ : 1799-1805.

10. Poznic M. Retinoblastoma protein: a central processing unit. J Biosci. 2009 ; 34 : 305-12.

11. Ohtani $K$. Implication of transcription factor $E 2 F$ in regulation of DNA replication. Front Biosci. 1999 ; 4 : 793-804.

12. Lundberg AS, Weinberg RA. Functional inactivation of the retinoblastoma protein requires sequential modification by at least two distinct cyclin-cdk complexes. Mol Cell Biol. 1998 ; 18 : 753-61.

13. Mittnacht S. Control of pRB phosphorylation. Curr Opin Genet Dev. 1998 ; 8 : 21-7.

14. Chew YP, Ellis M, Wilkie S, Mittnacht S. pRB phosphorylation mutants reveal role of $\mathrm{pRB}$ in regulating $\mathrm{S}$ phase completion by a mechanism independent of E2F. Oncogene. $1998 ; 17$ : 2177-6.

15. Gartel AL, Radhakrishnan SK. Lost in transcription: p21 repression, mechanisms, and consequences. Cancer Res. 2006 ; 65 : 3980-5.

16. Lukas J, Bartkova J, Bartek J. Convergence of mitogenic signalling cascades from diverse classes of receptors at the cyclin D-cyclin-dependent kinase $-\mathrm{pRb}$ controlled G1 checkpoint. Mol Cell 
Biol. 1996 ; 16 : 6917-25.

17. Neugut AI, Hayek M, Howe G. Epidemiology of gastric cancer. Semin Oncol. 1996 ; 3 : 281-91.

18. Liu EH, Qi LW, Wu Q, Peng YB, Li P. Anticancer agents derived from natural products. Mini Rev Med Chem. 2009 ; 9 : 1547-55.

19. Jones BA, Gores GJ. Physiology and pathophysiology of apoptosis in epithelial cells of the liver, pancreas, and intestine. Am J Physiol. 1997 ; 273 : 1174-88.

20. Kluck RM, Bossy-Wetzel E, Green DR, Newmeyer DD. The release of cytochrome $\mathrm{c}$ from mitochondria: a primary site for $\mathrm{Bcl}-2$ regulation of apoptosis. Science. $1997 ; 275: 1132-6$.

21. Manion MK, Hockenbery DM. Targeting BCL-2 related protein in cancer therapy. Cancer Biol Ther. $2003 ; 2$ : 105-14.

22. Trivedi PP, Roberts PC, Wolf NA, Swanborg RH. NK cells inhibit $\mathrm{T}$ cell proliferation via p21-mediated cell cycle arrest. J Immunol. 2005 ; 174 : 4590-7.

23. Sherr CJ. G1 phase progression: cycling on cue. Cell. $1994 ; 79$ : 551-5.

24. Kornberg RD, Lorch Y. Twenty-five years of the nucleosome, fundamental particle of the eukaryotic chromosome. Cell. 1999 ; 98 : 285-94.

25. Hume AJ, Finkel JS, Kamil JP, Coen DM, Culbertson MR, Kalejta RF. Phosphorylation of retinoblastoma protein by viral protein with cyclin-dependent kinase function. Science. 2008 ; 320 : 797-9.

26. Sherr CJ, Roberts JM. CDK inhibitors: positive and negative regulators of $\mathrm{G} 1$-phase progression. Genes Dev. 1999 ; 13 : 1501-12. 